\title{
Research on the Transformation of the General Curriculum System in Colleges and Universities
}

\author{
Xiangxin Liu \\ Department of Public Relations, Wuhan Railway Vocational Technological University \\ Wuhan, 430325, China
}

\begin{abstract}
As an important part of higher education and a powerful means of cultivating comprehensive talents. The curriculum system of general education is directly related to the success of general education. This paper will point out the difficulties and causes of the curriculum system construction of current general education and put forward some constructive suggestions by analyzing the current situation of the curriculum system construction of general education in colleges and universities in China. At the present stage, colleges and universities in China should set up professional management organization of general education, deepen the concept of general education, identify the goal of general education, and innovate the teaching method of general education as well as establish a scientific mechanism of evaluation.
\end{abstract}

Keywords-General education; Current situation; The curriculum system; Construction

\section{INTRODUCTION}

In the 1980 s, the disadvantages of excessive specialization of higher education were so obvious that the professionals who had been trained could not meet the requirements of socialist modernization. At that time, the trend of thought in general education had aroused attention countrywide, and colleges and universities had attempted to carry out the general education curriculum already. In 1995, some universities carried out the pilot project of cultural and quality education. For example, the School of Humanities and Social Sciences was established at Tsinghua University, which offered courses in humanities and social sciences to all students. Subsequently, many colleges carry out the curriculum system construction of general education based on their own reality, and bring the general education curriculum into the whole university talents training system, providing "generalist" talents for the society. However, there are also many problems in the practice of general education.

\section{GENERAL EDUCATION}

The concept of general education can date back to the 19th century in the United States. In the middle of 1980s, Taiwanese scholars transformed the thought of general education or liberal education, and formed the Chinese term "general education". This kind of translation is based on the understanding of "tong" and "knowledge" in the traditional Chinese culture. "Tong" is the meaning of proficiency, familiarity and knowing things. "Knowledge", that is, knowledge, common sense and insight. So general education is a kind of education in which students can acquire knowledge and broaden their horizon.

\section{THE CURRENT SituAtion OF GENERAL EDUCATION CURRICULUM AT UNIVERSITIES IN CHINA.}

\section{A. Draw lessons from the practical experience of American general education curriculum, but on the surface}

In the United States, there have been many achievements in the practical exploration of general education and general education curriculum in the past century. General education courses generally account for over $40 \%$ of the total curriculum, and some schools can reach up to $50 \%$, which fully reflects that schools attach great importance to the general education. A survey shows that 78 percent of American colleges and universities have made a clear intended learning outcome of general education. At present, the practice of general education in China is greatly influenced by American universities. However, we only focus on imitating something superficial such as the establishment of the organizational form of American universities, the external classification of general education courses, the freedom to choose courses and so on. But the essence and the core of general education curriculum are ignored [1]. 


\section{B. The form of classroom teaching and assessment are traditional and single.}

In China, the general education curriculum of colleges and universities includes the compulsory courses and optional courses of quality education. All the compulsory courses include political theory courses, foreign language courses, physical education and military courses and so on, which usually have unified requirements and carry on the unified examination in the whole school. There is little difference of these courses between different majors in the school. However, most of the optional courses of quality education are reported and set up by teachers independently. And teachers will design and decide the mode of evaluation, and students have freedom to choose. This kind of course covers a wide range of subjects, such as natural sciences, humanities, social sciences, languages, arts, computer, basic skills and other aspects. In the form of classroom teaching, most of them are traditional teaching forms, in which students accept knowledge passively. But other forms of teaching, such as special lectures, experiments and expert report, are very rare. And the application of new teaching mode such as flipped -classis almost extinct. In the way of assessment and evaluation, most of the courses adopt the way of small papers, which have lower requirements to students. Compared with the specific contents learned, the evaluation is more like a "formality", only including "pass" and "not pass" two forms.

\section{RESEARCH ON THE SOURCE OF GENERAL EDUCATION CURRICULUM IN CHINA}

In the process of the construction of general education curriculum system, various colleges and universities have made many efforts and produced a lot of achievements in order to improve the curriculum construction and cultivate comprehensive talents. But many measures have been taken to cross the river by feeling the stones for lack of experience, so a lot of problems have appeared.

\section{A. The management of the general curriculum system still has much room for progress}

At present, the general education courses at universities in China are not systematic, and more are just a simple list of public basic courses. There is little exploration of the links within the courses, which is against the purpose of general education that aims to eliminate barriers between traditional disciplines and give students a comprehensive understanding of knowledge [2].

In the management of the existing general education curriculum system, most of the general education courses are designed by the teachers themselves. After the approval of the school, students will have the access to choose classes. This kind of voluntary teaching mode will lead to the lack of overall design of the structure of the school's optional courses, and the consistency and relevance of the curriculum is doubtful. At the same time, the management on the assessment and evaluation of the optional courses in most schools are relatively loose because of the lack of post-evaluation management and control system.

\section{B. The preparation and comprehension of teachers for general education curriculum is inadequate.}

Most of the general education courses in colleges and universities in China are mainly guided by one-way teaching so that the classroom teaching lacks the cultivation, guidance and training of the students' learning methods, basic ability and critical thinking mode for students. The reason is that teachers don't understand the significance of general education curriculum completely. Some teachers simply view the general curriculum as a "task", an influential factor to get a title and a burden rather than their own intention. At the same time, the existing academic system requires teachers to pay more attention to scientific research instead of teaching [3] But it takes a lot of time to set up a general education course because teachers should do preparation for lessons, look up some information, do PPT and teaching evaluation except for giving lessons to students. In this background, the teachers will have their own considerations. So, it is inevitable for teachers to choose to slack off in the teaching preparation for the general curriculum, which leads to insufficient attention to the general curriculum. Of course, emphasis doesn't be placed on the general curriculum and the design of lessons is rather rigid. Even some teachers have directly set up general courses by reducing the requirements of specialized courses.

\section{The devotion of students for general education curriculum is insufficient.}

First of all, the students in colleges and universities do not know enough about the general courses and pay less attention to them. The general courses are more often called "general optional courses" or "optional courses" in China, which naturally gives students a feeling that they needn't to pay much attention to the courses.

Secondly, college students are careless in choosing general education courses. The current mechanism of selecting courses in colleges and universities is similar to "blind selection" because they choose courses without knowing the teaching style of the teachers and the main contents of the courses. In this context, students are not careful about their choice of general courses. Some students only pay attention to the title of the course, but they find the class is far away from what they think when they really attend it. And some students are only concerned whether the teachers will check the attendance and whether the final examination is easy to pass or not. I don't care much about the specific contents of my study. For the specific content of learning, they don't care at all.

Thirdly, college students do not invest enough time in general education courses. The course design of general optional courses takes little students' interests and needs into consideration, and the homework is hardly set after class. But because now the arrangement of students' spare time is rich and diverse, few students will devote their time to general education after class without clear requirements and guidance. Some schools do not even give specific scores in the final examination, just have two levels of "pass" and "not pass". And most teachers do not want to "embarrass students", resulting in the thought of students that they can pass the exam 
whatever they do. Accordingly, as for the time selection and allocation, students are more willing to spend their time in professional studies than in general education courses.

\section{THE RESEARCH ON THE TRANSFORMATION OF THE GENERAL CURRICULUM SYSTEM AT UNIVERSITIES IN CHINA}

\section{A. To deepen the idea of general education and establish the general curriculum committee}

General education is a kind of education that is as comprehensive as possible to cultivate students' independent personality and quality of independent thinking. It goes beyond utilitarianism and practicability, playing an important guiding role in the lifelong learning and building a learning society in the new era. As an educational concept, general education is also a mode of talent training. It is necessary to form a system on the curriculum and to make every general course have specific educational significance. To deepen the idea of general education, it must be carried out not only at the school management level, but also at the level of teachers and students, which requires that each school has an independent governing agency to carry out the relevant issues of general education such as the establishment of a general curriculum committee. The main function of the general curriculum committee is to be responsible for the top-level design and construction planning of the core curriculum of general education. In addition, effective management should be implemented in all aspects of the general education curriculum. For example, the inculcation of the concept of general education at all levels, the discussion and construction of the general curriculum scheme, the teaching requirements of general education courses for teachers in various disciplines, the exploration of various teaching forms of general education courses as well as the reform and innovation of the evaluation methods of general courses [4].

\section{B. The way of general classroom teaching and evaluation should be diversified}

First of all, the way of general classroom teaching should be diversified. The construction of general course system requires high-quality teachers who not only need to have the spirit of selfless devotion to general education and have a wide range of knowledge, but also should master and innovate their own teaching methods according to different courses. In teaching, according to the characteristics of the subject, various teaching methods such as classroom teaching, group discussion, research-based learning, thematic discussion and other ways are adopted to know more about the students' absorption and feedback of class [5]. The purpose is to make students focus more on the study of the course and Let them think deeply about the general curriculum and the internal learning methods while participating in the classroom activities. Therefore, the school should vigorously advocate the organization forms of multiple channels of general education curriculum.
Secondly, the evaluation methods of general education courses should also be diversified. One of the reasons for the formalization of general education courses is that the form of evolution is unitary ang the requirement for quality of evaluation is low. Consequently, schools should have higher requirements for the teaching quality of general education classes and establish a more scientific course evaluation mechanism. From the training aim of general education, highlighting the diversity, pertinence and vividness of examination methods. Except for the traditional written examination, the classroom interaction and course paper writing and other ways should be added to strengthen the regular assessment. Creating a curriculum assessment system which revolves around comprehensive evaluation and process evaluation by combining formative assessment and summative assessment. In the process of assessment, we should pay more attention to the development of students' comprehensive ability and personal quality. Compared with knowing students' mastery of knowledge by memorizing mechanically, teachers should concentrate more on whether students have their own thinking and new perspectives on the problem, and whether they use the knowledge learned to provide ideas for solving problems in the process of learning. The students ability of thinking and innovation should be improved by means of the tendency of evaluation, and the students' interest and habit of independent learning can be cultivated to realize the goal of general education, that is, to promote the all-round development of students.

\section{CONCLUSION}

Different colleges and universities have their own educational ideas and training goal, which is related to their orientation and social function. However, in the construction of general knowledge curriculum system, all colleges and universities should embody the "people-oriented" educational idea, and establish a professional management organization for general education. They are also expected to deepen the idea of general education, clear the goal of general education, innovate the teaching methods of general education and establish a scientific evaluation mechanism for the purpose of developing students into comprehensive people and meeting the needs of China's socialist modernization.

\section{REFERENCES}

[1] Yang Jiubin. General Education in the United States: The Achievement and Crisis over the Past Century [J]. Fudan Education Forum. 2012,10.

[2] Li Ping. The Situations, Problems and Countermeasures of General Education in China [J]. Journal of Education Institute of Jilin Province. 2008,11.

[3] Huang Tianhui. Comparison of General Education Modes between Peking University and Fudan University [J]. Modern Education Science. 2017,12.

[4] Feng Huimin, Huang Mingdong, Zuo Tian. Evaluation System and Index Design of Teaching Quality in College General Education [J]. Educational Research. 2012,11.

[5] Li Manli, Yang Li, Sun Haitao. An Investigation Report on General Education of University in China-Taking Four Colleges for instance, including Peking University, Tsinghua University, Renmin University of China, Beijing Normal University [J]. Research on Education Tsinghua University. 2001,2. 